\title{
Celebrity Endorsement and Stock Market Return
}

\begin{abstract}
Purpose - Celebrity endorsement advertising receives increased attention in the relevant literature. Approaching from the abnormal stock market return perspective, the current study investigates the potential risks and expected profit associated with celebrity endorsement. The factors that are included in this investigation are the attributes relating to celebrities and the endorsed firms.
\end{abstract}

Design/Methodology/approach - Data were collected from over 300 firms that use celebrity endorsements and are listed in two of the biggest stock exchanges in China. The study uses the event study method to analyze the proposed relationships.

Findings - Some of the findings in the current study are consistent with or contrast to those in previous research. Specifically, this study finds that the celebrities' demographics such as age and gender have little influence on financial return of the endorsed firm. However, investors respond rather negatively towards using actor celebrities to endorse a product or a brand, especially for high-tech products. The match-up endorsement has a positive effect on the firm's abnormal return.

Research implications - The current study has implications for the relevant literature and practitioners. Very few studies have used stock market return to measure celebrity endorsement effectiveness. This study provides insights into the influence of various factors associating with celebrities and the endorsed firm, extending the celebrity endorsement research into a broader domain. In particular, this study has practical implications for firms that have used or intend to use actor celebrity endorsement.

Originality/value - This study is the first to use event study method to comprehensively analyze influence of attributes relating to both the celebrities and the endorsed firms in China on stock market return.

Keywords: celebrity endorsement; abnormal stock return; match-up; actor celebrity; investment risk; China 


\section{INTRODUCTION}

Using celebrities has been a common marketing practice for firms to support or endorse their brand quality and corporate image. Admittedly using celebrity endorsement has a number of advantages. For instance, a celebrity can attract new users and even revive a product that has lost market share by creating new interest from consumers (Atkin and Block, 1983; Petty, Cacioppo and Shumann, 1983). A well-respected celebrity can also enhance brand equity (Till, 1998); build brand credibility in a short period of time and position a brand (Mullikin and Petty, 2006); affect consumers’ attitude towards a brand (Till, 1998); enhance brand recognition ((Petty and Mullikin, 2006); and create a distinct personality to the endorsed brand (McCracken, 1989). Despite these merits, research on effectiveness of celebrity endorsement is inconclusive (i.e. Spry, Pappu and Bettina Bornwell, 2011; White, Goddard and Wilbur, 2009).

Celebrity endorsement has become one of the most popular advertisement tools in China and takes up a large percentage of total advertising (see Ding, Molchanov and Stork, 2011). The endorsement, depending on popularity of the celebrity, can be excessively expensive. For instance, the endorsement fee for movie stars like Jackie Chan has been reported to be $\$ 2.55$ million, and for some less popular ones could still be over $\$ 1$ million (see Table 1). Despite such an expensive practice in China, using celebrities for brand endorsement is becoming prevalent. Selection of a celebrity in China is evidently dependent upon the fame and popularity of the celebrity, not on the basis of the relevance to the product or brand. In some cases, a popular celebrity (TV or movie actor) is seen to endorse multiple 
brands/products for different firms. Such practice leads to question the effectiveness and worthiness of celebrity endorsement for these Chinese firms.

Table I Examples of celebrity endorsement fees in China

\begin{tabular}{|c|c|c|c|c|c|}
\hline Celebrity & Nationality & Year & Products & fee $(\mathrm{m})$ & \multirow{9}{*}{$\begin{array}{l}\text { Source } \\
\text { http://news.xinhuanet.com/auto/2013- } \\
\text { 07/24/c_125055050.htm } \\
\text { http://auto.qq.com/a/20130125/000188.h } \\
\text { tm } \\
\text { http://digital.sina.com.hk/news/-7- } \\
\text { 1055863/1.html } \\
\text { http://auto.sina.com.cn/forum/2009-09- } \\
\text { 15/0938525047.shtml } \\
\text { http://sports.xinmin.cn/nba/2006/09/26/7 } \\
\text { 6256.html } \\
\text { http://dc.yesky.com/156/8038156.shtml } \\
\text { http://ac.jdgod.com/2014/zixun_0612/63 } \\
\text { 86.html } \\
\text { http://auto.sina.com.cn/forum/2009-09- } \\
\text { 15/0938525047.shtml }\end{array}$} \\
\hline $\begin{array}{l}\text { Sophie } \\
\text { Marceau }\end{array}$ & France & 2014 & $\begin{array}{l}\text { CITROEN } \\
\text { DS }\end{array}$ & $\$ 1.6$ & \\
\hline Brad Pitt & America & $\begin{array}{l}2013- \\
2014\end{array}$ & $\begin{array}{l}\text { CADILLA } \\
\text { C XTS }\end{array}$ & & \\
\hline $\begin{array}{l}\text { Leonardo } \\
\text { DiCaprio }\end{array}$ & America & 2011 & $\begin{array}{l}\text { OPPO } \\
\text { Finder }\end{array}$ & $\$ 5$ & \\
\hline $\begin{array}{l}\text { Michael } \\
\text { Phelps }\end{array}$ & America & 2009 & MAZDA 6 & $\$ 2.9$ & \\
\hline $\begin{array}{l}\text { Shane } \\
\text { Battier }\end{array}$ & America & $\begin{array}{l}2006- \\
2009\end{array}$ & PEAK & $\$ 4$ & \\
\hline \multirow[t]{3}{*}{$\begin{array}{l}\text { Jackie } \\
\text { Chen }\end{array}$} & \multirow[t]{3}{*}{$\begin{array}{l}\text { Hong } \\
\text { Kong, } \\
\text { China }\end{array}$} & $\begin{array}{c}2008- \\
2014 \\
2012- \\
2013\end{array}$ & $\begin{array}{l}\text { Cannon } \\
\text { EOS } \\
\text { Gree Air } \\
\text { Conditioner }\end{array}$ & $\begin{array}{l}\$ 1.4 \text { per } \\
\text { year }\end{array}$ & \\
\hline & & 2007 & $\begin{array}{l}\text { MITSUBIS } \\
\text { HI GAL }\end{array}$ & $>=\$ 1.3$ & \\
\hline & & $\begin{array}{l}2014 \\
2014\end{array}$ & $\begin{array}{l}\text { Pepsi NEX } \\
\text { Samsung }\end{array}$ & Average & \\
\hline Lee & South & 2013 & Taobao & $\$ 2$ per & http://news.sohu.com/20140330/n39744 \\
\hline MinHo & Korea & $\begin{array}{l}2009 \\
2009\end{array}$ & $\begin{array}{l}\text { Levis } \\
\text { CADILLA } \\
\text { C }\end{array}$ & company & 0080.shtml; \\
\hline \multirow[t]{3}{*}{$\begin{array}{l}\text { Ziyi } \\
\text { Zhang }\end{array}$} & \multirow[t]{3}{*}{$\begin{array}{l}\text { Hong } \\
\text { Kong, }\end{array}$} & $\begin{array}{c}2009- \\
2011\end{array}$ & BENZ SLK & $\$ 3$ & \multirow[t]{3}{*}{$\begin{array}{l}\text { http://auto.sina.com.cn/forum/2009-09- } \\
\text { 15/0938525047.shtml }\end{array}$} \\
\hline & & $\begin{array}{c}2013 \\
2007- \\
2010 \\
2007- \\
2008 \\
2007\end{array}$ & $\begin{array}{l}\text { BMW } \\
\text { CADILLA } \\
\text { C CTS } \\
\text { Amway } \\
\text { Nutrilite } \\
\text { Lenovo }\end{array}$ & $\begin{array}{l}\$ 26.3 \\
\$ 2.7\end{array}$ & \\
\hline & & 2006 & $\begin{array}{l}\text { Yili Satine } \\
\text { milk }\end{array}$ & $\$ 2.5$ & \\
\hline \multirow[t]{4}{*}{ Xiang Liu } & \multirow[t]{4}{*}{ China } & 2006 & $\begin{array}{l}\text { Senda floor } \\
\text { The Bank } \\
\text { of }\end{array}$ & $\$ 2.5$ & $\begin{array}{l}\text { http://auto.sina.com.cn/forum/2009-09- } \\
\text { 15/0938525047.shtml }\end{array}$ \\
\hline & & 2007 & $\begin{array}{l}\text { Communica } \\
\text { tion of } \\
\text { China }\end{array}$ & $\$ 2.5$ & \\
\hline & & 2004 & $\begin{array}{l}\text { China Post } \\
\text { EMS }\end{array}$ & $\$ 1.2$ & \\
\hline & & 2004 & KIA Pride & $\$ 0.03$ & \\
\hline $\begin{array}{l}\text { Yongyuan } \\
\text { Cui }\end{array}$ & China & $\begin{array}{l}2014- \\
2024\end{array}$ & $\begin{array}{l}\text { Some } \\
\text { Furniture } \\
\text { brand }\end{array}$ & $\$ 22$ & $\begin{array}{l}\text { http://news.sohu.com/201403 } \\
\text { 30/n397440080.shtml }\end{array}$ \\
\hline
\end{tabular}

Notes: the RMB foreign exchange rate against USA dollar is based on the last day of each year, such as 6.1(2013), 6.3(2012) and 6.5(2011). The exchange rate of 2016 is around 6.6. 
Research has shown that the effectiveness and business ROI (return on investment) are determined by the celebrity's characteristics including celebrity-brand match (i.e. Silvera and Austad, 2004), credibility (i.e. McCracken, 1989) and personas of the celebrity (i.e. Armstrong, 1990; Byrne, Whitehead and Breen, 2003). However, in the case of Chinese market, endorsement by popular actors or TV stars, despite any mismatch, seems to be rather dominant. A few studies have attempted to analyze this phenomenon from cultural perspective. For instance, Gan (2006) examined the influence on celebrity endorsement on young Chinese consumers. Similarly, Hung, Chan and Tse (2011) attempted to assess the relationship in a more complex model and found that celebrity worship had impact on the endorser effects. Very few studies have analyzed these relationships in an integrative manner.

On the other hand, the metrics that have been used to measure the endorsement effects vary across studies. Most research approaches the effects from consumer perspective, assessing brand related outcomes (i.e. brand equity) (i.e. Boyd and Shank, 2004; Kamins and Gupta, 1994; Escalas and Bettman 2009; Koerning and Bord, 2009; Lynch and Schuler, 1994; Misra and Beatty, 1990; 2000; Spry, Pappu and Bettina Cornwell, 2011; Till and Busler, 1998). Others examine the sales increase (i.e. Jain, 2011). However, quantifying these metrics are not easy, as some qualitative and compounding factors are also involved. The increased use of social media in the advertising business also complicates measure of celebrity endorsement effects. The metrics of page views, impressions, shares, followers, likes may not reflect actual sales increase (Taneja, 2014). As Evan Morgenstein, the President and CEO of CeleExperts stated, “most companies expect that not everything in a celebrity-centric deal can be evaluated using traditional metrics”. 
Some researchers (i.e. Agrawal and Kamakura, 1995; Ding, Molchanow and Stork, 2011) adopt the firm's abnormal stock return to measure the celebrity effects and contend that share price is more responsive to fluctuating circumstances taking place in business. Russell, Mahar, and Drewniak (2005) indicate that stock market fluctuates with celerity positive or negative events. Any information relating to the endorser would affect investors' decision. The abnormal stock return refers to the differences between a single stock or portfolio's performance and the expected return over a predetermined period of time, represented as abnormal stock return $=$ actual return - expected return. Even study methodology is often used to measure the abnormal returns. This method provides a particular means to addressing the impact of celebrate endorsement on a firm's expected future profits (see Agrawal and Kamakura, 1995)

Consistent with foregoing discussion, the current study, with a focus on China, takes an integrative approach to examine the factors that may influence celebrity endorsement effects through measuring the firm's abnormal stock return. This research builds upon Ding et al.’s (2011) study which was based on the USA context, and, to a certain extent, replicates their approach in Chinese counterpart. The factors selected for analyses in this study are consistent with those in Ding et al.'s, and are deemed to be relevant for the research context after the primary researcher's field experiment. These factors are directly and indirectly related to celebrities including demographic information, multiple endorsements, media announcement, the selected firms' book values listed on the stock market, and the firm's product attributes. The following section presents a brief literature review and offers the 
relevant hypotheses. Methodology is outlined subsequently to test the hypotheses. Results and discussion are presented with implications concluding this paper.

\section{HYPOTHESES FORMATION}

\subsection{Celebrity Demographics}

Prior studies (i.e. Fizel, McNeil, and Smaby, 2008; Fink, Cunningham, and Kensicki, 2004) have shown that the celebrity's personal characteristics have impact on the endorsement outcome. Positive outcomes are often generated by the celebrity’s expertise, trustworthiness, attractiveness, familiarity, and likeability (Ohanian 1990). However, findings on the celebrity's demographic background are inconclusive. Ding, Molchanov and Stork (2011) found that the celebrity's gender, age and occupations have very little influence on the endorsement effectiveness (see). Other researchers (i.e. Fizel, McNeil, and Smaby, 2008; Fink, Cunningham, and Kensicki, 2004) show that sports stars generally are more appealing to a large portion of consumers or investors. In China, sports star and actors appear to popularize the advertising world. Hung, Chan and Caleb (2011) indicate that celebrityworship in China is particularly prevalent and has a substantial impact on Chinese consumers' purchase intention. On the other hand, Chinese consumers tend to purchase products endorsed by celebrities of their similar ages (see Chan, Ng and Luk, 2013). Drawing on these studies, the study offers the following hypothesis:

H1: Celebrity demographics have influence on the abnormal return of the endorsed firm.

\subsection{Multiple Endorsement}

Selection of a celebrity in China is primarily dependent upon popularity of the 
celebrity. For instance, a popular TV show attracts audience's attention to their favorable role, hence to the actor who plays that role. The actor often becomes marketers' target for advertising regardless of her relevance to the endorsed product or brand (e.g. Chinese actor Fan Bing Bing, see Fashionbi, 2014). Popularity of the celebrity results in multiple endorsements. Some firms tend to use a few celebrities to endorse their products and hope to generate multiple effects (Hsu and McDonald, 2002). In other cases, several firms use the same celebrity to endorse a wide range of products for the same manufacturer.

Consumers often raise doubt on credibility of the endorsed products as they believe the endorse firm simply uses the celebrity fame to increase sales, and the product quality has little relevance to the fame (Hsu and McDonald, 2002). The outcome of multiple endorsements by a celebrity could be counterproductive (Louie and Obermiller, 2002). In particular, when the celebrity fame is fading or turning to be negative, the endorsed brands may become less popular. For instance, Tiger Woods' scandal resulted in consumers rather following the celebrity's stories that cause loss of fame rather than the endorsed brand. These incidences likely lead to celebrity vamping (Rossiter and Percy, 1997). Previous research has not reached a unified conclusion on multiple endorsement effects. Tripp, Jensen and Carlson (1994) indicated that endorsement effect may be reduced when one celebrity endorse a few brands. Hung et al. (2011) found that Chinese consumers tend to have negative response towards the celebrities and the endorsed products and brands when they are excessively involved in endorsements. Consistent with these studies, the study proposes:

H2: Multiple endorsements have a negative influence on the abnormal return of the endorsed firm 


\subsection{The Endorsed Firm's Book Value}

Prior research on celebrity endorsement is primarily focused on the characteristics directly associating with celebrities or the endorsing outcomes. Very few studies have attempted to examine attributes relating to the endorsed firm. Knowingly celebrity endorsing fees take a large share of the firm's advertising budgets. Using celebrities implies the firm's financial soundness which is often reflected on the firm's listed book value. If the listed value is comparatively low, investors may perceive it as high risk investment, despite popularity of the endorsing celebrity. In some cases, using popular celerity for firms with low financial value is detrimental to shareholders' equity and result in potential agency risk. This leads to the following hypothesis:

H3: The endorsed firm's book value has a significant influence on the abnormal return of the endorsed firm.

\subsection{Media Announcement}

Media announcement is often the first step in engaging celebrity endorsement. Once determining use of the celebrity and obtaining his or her consent, the firm organizes press conference and announce contractual agreement with the celebrity. Very little research has attempted to examine its financial impact. Media announcement can send investors a signal that the firm is financially sound and able to afford substantial celebrity endorsing fees. Using celebrity endorsement may increase the firm's financial performance. Following the media announcement, potential investors are anticipated to instil their investment in the stock market. This view informs the following hypothesis:

H4: Media announcement has a significant influence on the abnormal return of 
the endorsed firm.

\subsection{Match up Endorsement}

The celebrity effect, according to the match-up theory, can be improved when the endorsing celebrity matches endorsed product (Kamins 1989). Previous research has primarily focused on positive psychology effect, such as brand recall rate (Misra and Beatty 1990), shift affect from spokesperson to brand (Misra and Beatty 1990), attitudes towards advertisement (Kamins 1990), brand affect (Misra and Beatty 1990), brand atttiude (Misra and Beatty 1990, Till and Busler 1998, Till and Busler 2000), purchase intention (Till and Busler 2000). Seno and Lukas (2007) indicate that celebrity endorsement is one form of cobranding and brand-alliance, which often makes endorsed brand difficult to replicate.

Branding can be reinforced by match-up endorsement. Koerning and Bord (2009) found that sport consumers would have more positive attitudes when athlete celebrities endorse sport brands than non-sport products. For instance, positive return can only be generated for golfrelated products if Tiger Woods is the product endorser.

Ding, Molchanov and Stork (2011) collected a sample of 101 endorsements from 1996 to 2008 in USA firms and reported that significant abnormal stock return was achieved in match-up endorsements, Indeed, some researchers (i.e. Mittelstaedt, Riesz, Burns, 2000) argue that the match-up endorsement is more effective than the celebrity fame. Hence, the study proposes:

H5: Match-up endorsement has a positive influence on the abnormal return of the endorsed firm.

Consistent with the match-up theory, it is plausible to posit that, in the case of high- 
tech product, consumers prefer someone who has relevant expertise on the product to endorse the quality, rather than a famous actor or a sports star. For instance, health professionals or doctors, rather than actors or TV hosts would be more appropriate to endorse health supplements or medical products. Technical experts have more credit to endorse high technology oriented products. However, investors seem to have different views on their investments. Financial soundness of a firm is a more important factor in their decision on investment. Using an expensive celebrity is indicative of the firm's financial capability (see Clark, Cornwell, and Pruitt, 2002; Cornwell, Pruitt, and Ness, 2001). Indeed, Ding et al. (2011) found that stock market reacted positively towards celebrity endorsement in high-tech firms. Consistent with their study, the study offer the following hypothesis:

H6: celebrity endorsement in high-tech firms has a positive effect on the abnormal return of the endorsed firm.

\section{METHOD}

\subsection{Sample}

The sample was selected from firms listed on the Shanghai and Shenzhen Stock Exchanges. Instead of sourcing information from newspapers as most researchers do, we generate the data through the internet. This option was determined on: all news in China is disseminated through websites including sina, sohu, 163 and ifeng; all popular newspapers have their own websites to publish the e-version news which is exactly the same as what is published on the hardcopy. This approach is also consistent with that of Ding et al.'s (2011) study.

\subsection{Procedure}


Three steps were undertaken in the data collection to ensure accuracy of collected information. Firstly, we selected firms that were listed on Shanghai and Shenzhen Stock Exchanges. Subsequently we manually examined each firm by using Google and Baidu, and filtered those that used celebrity endorsements. Baidu (www.baidu.com) occupies about 80\% search engine market share in China, while google about $15 \%$ market share. As a result, a usable sample of 302 firms with corresponding celebrity endorsements was generated. Secondly, we searched the time for each endorsement through the company's website and those of the major media in order to obtain the precise announcement data. Finally, we verified the data by duxiu newspaper database. This database provides the full text of the mass newspapers in China, and daily updates of major newspapers. This search reinforced data accuracy. Admittedly this process may not obtain all celebrity endorsements in each firm. However, the missed events are rather trivial to reach wide investment community, and deemed to have insignificant impact on the firm's abnormal stock return.

Additionally, we applied another four criteria to validate the data: endorsement time, confounding events, estimation window, and overlapping events. Specifically, we deleted the cases that used celebrity endorsements prior to listing in the stock exchange. We carefully examined the confounding events that may occur in the event window through CNINF database, including revenue proclamation, declaring dividends, stock issuance, significant changes in tax policy, the introduction to a new brand or a new product, the occurrence of big labor disputes, company rename, merger negotiations, restructuring, mergers, etc. We then deleted the cases that involve Langsha (Xuxidi), Meierya (Mayanli), Weiwei (Wuxiaoli), MideaGroup (Douxiao and Zhoudongyu), Nanfanghuitong (Yuanquan), Guyuelongshan 
(Chenbaoguo), SuningGroup (Zhouhaimei), Wangfujing (Chenguanxi), Shanghaijiahua

(Wupeici). We also deleted the firms that its estimation window was less than 255 days.

Lastly, we filtered those overlapping event windows by several announcements when the firm used several celebrities. For example, the Yili Group contracted with Liu Xiang - one of the most popular Olympic champions as Yili Group spokesman on February 27, 2006, then signed up with Zhang Yunhan as the endorser on March 1, 2006, and subsequently announced another popular Olympic champion Guojinjin as endorser for its LGG sour milk. However, no stock exchange occurred for Yili between February 18 and March 8. Hence we deleted the endorsements by Liu xiang and Zhang Yunhan. As a result of this process, 87 celebrity endorsement announcements including 60 firms and 86 celebrities were generated.

Consistent with Agrawal and Kamakura's (1995) study, event study method was deployed to analyze the information. Event study is a statistical method to assess the effect of an event on a firm's stock price change. Agrawal and Kamakura provided the rationale for using this method to measure abnormal returns and stated: "event study methodology measures the magnitude of the effect that an unanticipated even has on the expected profitability and risk of a portfolio of firms associated with that event (p57). The reasons for opting for this method are as follows: 1) although directly measuring the impact of celebrity endorsement on the firm's future sales or profits is difficult, event study can be used to examine how the investors make investment decisions; 2) use of celebrity adverting is a big financial decision for the firm due to substantial endorsement fees. It often attracts attention from the media as well as the investors who often make investment decision on the firm's financial future performance. Their decisions are reflected on stock price’s change. Hence, 
the abnormal market return of the endorsed firm is determined to be a valid measure to assess the endorsement effect (see Ding and Molchanov, 2011).

\subsection{Data Analysis}

Consistent with the analytic approach adopted by Agrawal and Kamakura (1995) and MacKinlay (1997), we analyzed the data using R software and stored all financial data in CSMAR database ${ }^{1}$. We coded the announcement day as the event day $\left(T_{0}\right)$, when the mainstream media reported the contract sign-up day between the firm and the celebrity. If the stock market was closed in $T_{0}$, then the next exchanging time was considered the event day. All other window days were compared to the event day. For example, +20 day $\left(T_{20}\right)$ is the $20^{\text {th }}$ day after the event day, and -20 day $\left(\mathrm{T}_{-20}\right)$ is the $20^{\text {th }}$ day before the event day. The time interval $[-10,10]$ is between $T_{-10}$ and $T_{10}$. The estimation window is the time interval in which we estimated the normal return; while event window is the interval in which we test abnormal stock return. Following Ding, Molchanov and Stork’s (2011) recommendation, we choose 255 exchanging days to be the estimation window, that is interval [-300,-46], and 21 days, [$10,10]$ to be the event window. The most frequently used market model was used to generate normal return. According to the market model, the normal return to asset $\mathrm{i}$ at time $\mathrm{t}$ (in estimation window) $\mathrm{R}_{\text {it }}$ can be expressed as a linear function of the returns from a portfolio of all marketed assets $\mathrm{R}_{\mathrm{mt}}$ as shown below (Equation 1):

(1) $R_{i t}=\alpha_{i}+\beta_{i} R_{m t}+\varepsilon_{i t}, E\left(\varepsilon_{i t}\right)=0 \operatorname{VAR}\left(\varepsilon_{i t}\right)=\sigma_{\varepsilon_{i}}$, where $\alpha_{i}$ is the constant term, $\beta_{i}$ is the parameter that measures the sensitivity of $R_{m t}$ to $R_{i t}$;; $\varepsilon_{i t}$ is the error term.

The abnormal stock return for stock $\mathrm{i}$ on the day t (in event window) is as follows

${ }^{1}$ CSMAR is the major database for financial and accounting in China. We can visit it by URL: http://www.gtarsc.com/ 
(Equation 2): (2)AR $R_{i t}=R_{i t}-\left(\hat{\alpha}_{i}+\hat{\beta}_{i}+R_{m t}\right.$, where $\hat{\alpha}_{i}$ is the estimate of $\alpha_{i}$ with OLS (Ordinary Least Square), $\hat{\beta}_{i}$ is the estimate of $\beta_{i}$ with Ordinary Least Square (OLS). Considering that $A R$ may not be good enough to test the effect of event on stock price change, we then used $A A R$ and $C A R$ for further analyses. $A A R_{t}$ is the average abnormal stock returns of event day of $\mathrm{t}$, and it is calculated as below:

(3) $A A R_{t}=\left(\sum_{i=1}^{n} A R_{i t}\right) / n, \quad \sigma^{2}\left(A R_{i t}\right)=\sigma_{\varepsilon_{i}}^{2}+\frac{1}{L_{1}}\left[1+\frac{\left(R_{m t}-\widehat{\mu}_{m}\right)^{2}}{\widehat{\sigma}_{m}^{2}}\right]$,

Where $n$ is the length of event window, $L_{1}$ is the length of estimation window. In the case of large $L_{1}$, such as 455 in this study, the second part of $\sigma^{2}\left(A R_{i t}\right)$ is almost zero and excluded from the analyses. $C A R_{t_{1}, t_{2}}$ is the cumulative average abnormal stock returns of $A A R_{t}$, and it have two kinds of CAR to calculate ${ }^{15}$. For this research, $C A R_{t_{1}, t_{2}}$ is calculated by equation 4: (4)CAR $t_{t_{1}, t_{2}}=\Sigma_{t=t_{1}}^{t_{2}} A R_{i t}$. Moreover, it is necessary to aggregate all events' $C A R$ to get more result. We use equation (5) to test its $C A R$ with no clustering assumption and large

(5) $\overline{A R_{t}}=\frac{1}{N} \sum_{i=1}^{N} A R_{i t}, \quad \operatorname{var}\left(\overline{A R_{T}}\right)=\frac{1}{N^{2}} \sum_{i=1}^{N} \sigma_{\varepsilon_{i}}^{2}$, where $\mathrm{N}$ is the number of events.

\section{RESULTS}

\subsection{AR and CAR test (testing $H 2$ and $H 4)$}

Before we calculated $A R$, we endeavored to make sure appropriateness of estimation functions. With R regress function, we checked the statistical number of estimation functions. For $R$ square, $p$ value and $F$ value, the selected cases were considered acceptable for statistical testing. Table 2 shows average abnormal stock returns across event window, which includes average abnormal stock return and cumulative abnormal stock return starting at 10 
days prior to the announcement $\left(\mathrm{T}_{-10}\right)$. In all $A A R$, there are two $\mathrm{T}$ value numbers $\left(\mathrm{T}_{-7}\right.$ and $\left.\mathrm{T}_{-3}\right)$ significant at $10 \%$ level. Although the $A A R$ of event day is positive, none appears to be significant. This finding indicates that announcement day exerts no effect on the firm's stock change. Figure 1 shows the movement of average abnormal stock return in the event window. The average abnormal stock return is similar to fluctuating broken line, as shown in Figure 1. The average abnormal stock return present Figure 1 shows insignificant effect from endorsement announcement. On this basis of this finding, H4 is not supported.

Table II average abnormal stock return in event window

\begin{tabular}{ccccc}
\hline Event day & AAR $(\%)$ & Z value & T value & Cumulative Abnormal stock return (CAR,\%) \\
\hline-10 & $0.34 \%$ & 1.44 & 1.36 & $0.34 \%$ \\
-9 & $-0.21 \%$ & -0.89 & -1.06 & $0.13 \%$ \\
-8 & $0.03 \%$ & 0.12 & 0.15 & $0.16 \%$ \\
-7 & $0.31 \%$ & 1.33 & $1.69^{*}$ & $0.47 \%$ \\
-6 & $0.09 \%$ & 0.38 & 0.45 & $0.56 \%$ \\
-5 & $-0.34 \%$ & -1.43 & -1.62 & $0.22 \%$ \\
-4 & $0.31 \%$ & 1.32 & 0.82 & $0.53 \%$ \\
-3 & $-0.37 \%$ & -1.56 & $-1.93^{*}$ & $0.17 \%$ \\
-2 & $-0.02 \%$ & -0.07 & -0.07 & $0.15 \%$ \\
-1 & $0.10 \%$ & 0.44 & 0.38 & $0.25 \%$ \\
0 & $0.36 \%$ & 1.54 & 1.47 & $0.62 \%$ \\
1 & $0.01 \%$ & 0.03 & 0.02 & $0.62 \%$ \\
2 & $0.06 \%$ & 0.26 & 0.32 & $0.69 \%$ \\
3 & $0.10 \%$ & 0.41 & 0.46 & $0.78 \%$ \\
4 & $0.06 \%$ & 0.24 & 0.28 & $0.84 \%$ \\
5 & $-0.26 \%$ & -1.10 & -1.18 & $0.58 \%$ \\
6 & $0.12 \%$ & 0.52 & 0.51 & $0.70 \%$ \\
7 & $0.32 \%$ & 1.35 & 1.45 & $1.02 \%$ \\
8 & $-0.31 \%$ & -1.32 & -1.62 & $0.71 \%$ \\
9 & $0.14 \%$ & 0.61 & 0.73 & $0.85 \%$ \\
10 & $0.18 \%$ & 0.77 & 0.75 & $1.03 \%$ \\
\hline
\end{tabular}

Note: event day 0 is the announcement day and ${ }^{*}$ means significant at $10 \%$ level using twotailed test.

The cumulative abnormal stock return of interval $\left(\mathrm{T}_{-10}, \mathrm{~T}_{10}\right)$ is show in Figure 2. We also 
calculated several sub-intervals’ cumulative abnormal stock returns. Every cumulative abnormal stock return starts at $\mathrm{T}_{-10 .} \mathrm{A}_{\mathrm{S}}$ shown in Figure 2, each cumulative abnormal stock return is positive, and there is a uphill from [-10,0]. However, every cumulative abnormal stock return is not significant. The results appear in Table 3. All different interval cumulative abnormal stock returns are positive, and cumulative abnormal stock returns starting at $\mathrm{T}_{0}$ and $\mathrm{T}_{-1}$ are bigger than others which start with $\mathrm{T}_{-3}$ and $\mathrm{T}_{-5}$ (see Table 2 ). The cumulative abnormal stock return (Table 1) is increasing over time. However, all cumulative abnormal stock returns in Table 2 are not significant. Hence, $\mathrm{H} 2$ is confirmed.

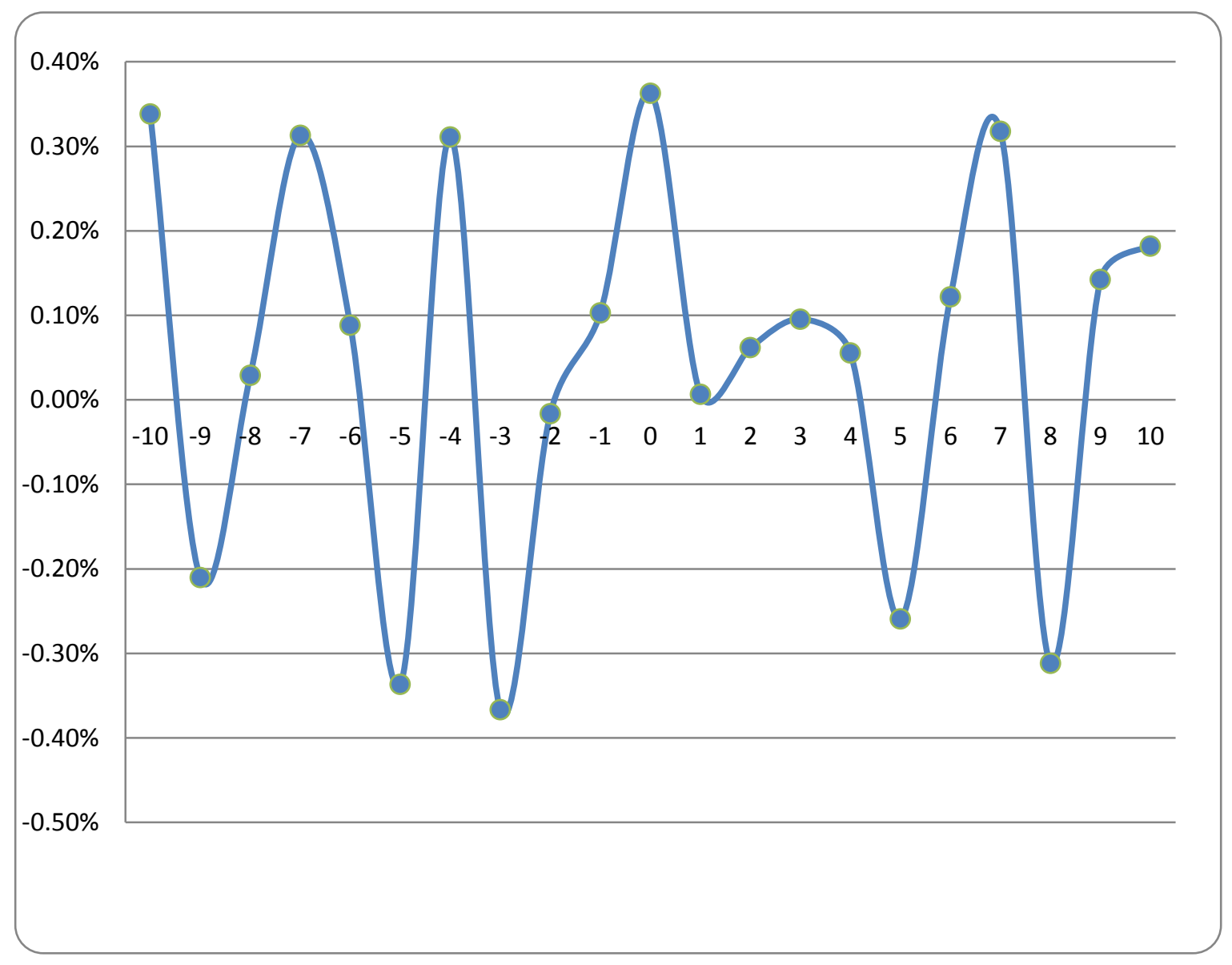

Figure 1: the dynamics of average abnormal stock returns through the event windows, and it start at $\mathrm{T}_{-10}$. 


\subsection{Testing H1, 3, 4 and 6}

To test how the attributes of celebrities and the listed firms affect the abnormal stock return, we run 11 separate cross-sectional regressions using ordinary least squares. The regression function is as follows (Equation 6):

(6) $C A R_{i}=\gamma_{i}+\delta_{i} \chi_{i}+\varphi_{i}$ where $C A R_{i}$ is the cumulative abnormal stock return of stock $\mathrm{i}$ in event windows of $\left(\mathrm{T}_{-10}, \mathrm{~T}_{10}\right)$ or $\left(\mathrm{T}_{0}, \mathrm{~T}_{10}\right), \gamma_{i}$ is the constant, $\delta_{i}$ is the parameter that measure the effect of impact of characteristic on abnormal stock return of stock of $i, \chi_{i}$ is the dummy variable, $\varphi_{i}$ is the error term.

Table III various sub-interval cumulative abnormal stock return

\begin{tabular}{|c|c|c|}
\hline $\begin{array}{l}\text { Event } \\
\text { window }\end{array}$ & Cumulative abnormal stock return & value $^{\mathrm{Z}}$ \\
\hline$(0,+1)$ & $0.37 \%$ & $1^{1.1}$ \\
\hline$(0,+2)$ & $0.43 \%$ & $6^{1.0}$ \\
\hline$(0,+3)$ & $0.53 \%$ & $2^{1.1}$ \\
\hline$(0,+4)$ & $0.58 \%$ & $1^{1.1}$ \\
\hline$(0,+5)$ & $0.32 \%$ & $6^{0.5}$ \\
\hline$(0,+7)$ & $0.76 \%$ & $5^{1.1}$ \\
\hline$(0,+10)$ & $0.78 \%$ & $9^{0.9}$ \\
\hline$(-1,0)$ & $0.47 \%$ & $0^{1.4}$ \\
\hline$(-1,+1)$ & $0.47 \%$ & $6^{1.1}$ \\
\hline$(-1,+10)$ & $0.88 \%$ & $8^{1.0}$ \\
\hline$(-3,0)$ & $0.08 \%$ & $8^{0.1}$ \\
\hline$(-3,+3)$ & $0.25 \%$ & $0^{0.4}$ \\
\hline$(-5,0)$ & $0.06 \%$ & 0.1 \\
\hline
\end{tabular}




\begin{tabular}{cccc}
\hline & & 0 \\
$(-5,+5)$ & $0.02 \%$ & \multicolumn{2}{c}{0.0} \\
$(-10,+10)$ & $1.03 \%$ & \multicolumn{2}{c}{0.9} \\
\hline
\end{tabular}

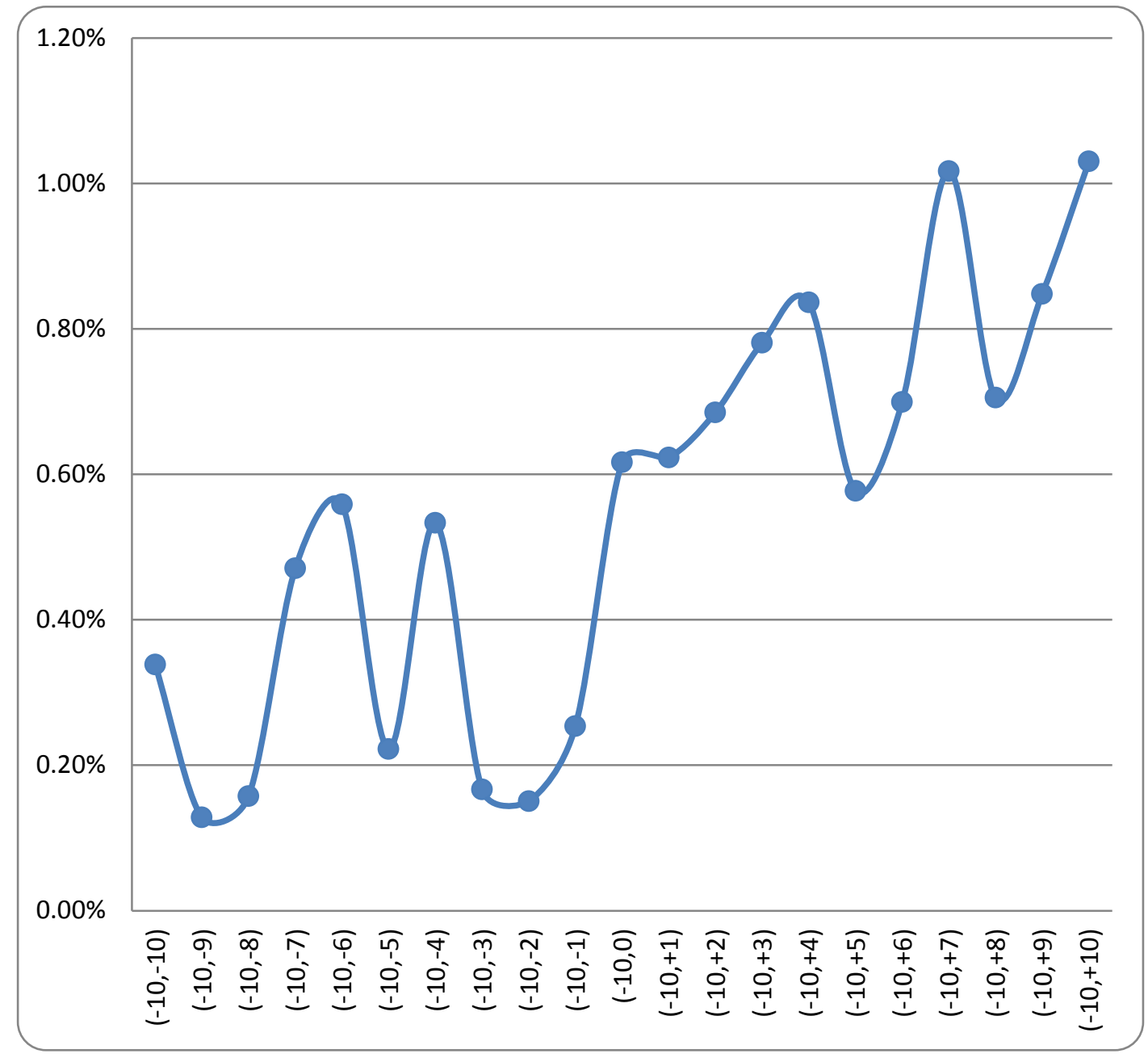

Figure 2: various sub-interval cumulative abnormal stock return starting at $\mathrm{T}_{-10}$

We use real values in function for these three characters. More precisely, we use the endorser demographics, book value of listed firms, and assets as the size of listed firms. In addition to these real values, we use dummy values to represent the characteristics of the firm and endorsers. Unlike the match-up in Ding's study, we conducted a survey on selected stock investors to measure the match-up between endorser and firm. We asked their views and 
perceptions by using the 7 -likert scale $(1=$ totally inappropriate, and $7=$ entirely appropriate. In data analysis, we coded the values of $-1,0$ and 1 to the average numbers of match-up that are [1,2], [3,5] and [6,7] respectively.

We classified endorsers’ professions into four categories: actors, singers, athletes and others including TV hosts, composers, entrepreneurs, and models. We set the value for each of these professions as 1 and 0 in dummy regression analyses. Some firms had used several celebrities. In this case, we set the value for these celebrities as 1 . We also set dummy value as 1 in the case of one celebrity endorsing many firms, while the value as 0 when the celebrity endorsed only one firm.

To test the celebrity endorsement effect in high-tech firms, we selected these firms using the categories established by National Bureau of Statistics of China 2006. There are 15 high-tech industries including information chemical manufacturing, pharmaceutical manufacturing, public software services, nuclear fuel processing. The firms selected for analyses in this study are four high-tech industries: electronic information, household appliances, biopharmaceuticals, pesticides and fertilizers industries.

The results show that when the dependent variable is the cumulative abnormal stock return in interval of $\left(\mathrm{T}_{-10}, \mathrm{~T}_{10}\right)$ and $\left(\mathrm{T}_{0}, \mathrm{~T}_{10}\right)$, the coefficients of the celebrity's age, gender are insignificant. H1 is not supported. However, the match-up functions are 0.19 and 0.10 , which are significant at $10 \%$ and $5 \%$ level. This result supports the match-up theory. The stock market reacts more positively when the celebrity's profession matches the product he or she endorses. Consistent with the results, H5 is confirmed.

The results present in Table 4 also show that the effect of actor endorser on 
cumulative abnormal stock return of interval $(-10,+10)$ is $-0.20(p<.10)$. However, the coefficients are positive for other professions, albeit not significant. This finding indicates that stock market in China reacts negatively towards endorsement by actors. The coefficients of function are not significant in all two interval's cumulative abnormal stock return while testing the effects of the firm's assets, celebrity's gender, and age. However, the effects of the firm's book value is significant $(\beta=.19)$, and the CAR in interval $(0,+10)$ is significant ( $p$ $<.10)$. This finding indicates that the stock market in China reacts positively towards high book value’s company. H3 is supported.

The results also show that the impact of high-tech firms on cumulative abnormal stock return in $(0,+10)$ is -0.22 is significant $(\mathrm{p}<.05)$, but not significant when interval is $(-$ $10,+10)$. The effect is also negative. When we analyze the correlation of high-tech and matchup, it is $-0.44(p<.0005)$. The match-up effects for the average of high-tech firms is -0.23 , 0.57 for non- high-tech firms. The finding indicates that investors have negative attitude towards celebrities endorsing for high-tech firms. Hence, H6 is not supported. 
Table VI The impact of characteristics of celebrity and firms on CAR

\begin{tabular}{|c|c|c|c|c|c|c|}
\hline \multirow[t]{2}{*}{$\begin{array}{l}\text { Independent } \\
\text { variables }\end{array}$} & \multirow[t]{2}{*}{$\begin{array}{l}\text { Expected } \\
\text { relationship }\end{array}$} & \multirow[t]{2}{*}{$\begin{array}{l}\text { Types of } \\
\text { Variable }\end{array}$} & \multicolumn{2}{|c|}{$\begin{array}{c}\text { Panel Data } 1 \text { : CAR } \\
(-10,+10)\end{array}$} & \multicolumn{2}{|c|}{$\begin{array}{l}\text { Panel Data } 2 \text { : CAR } \\
\qquad(0,+10)\end{array}$} \\
\hline & & & Coefficient & T value & Coefficient & T value \\
\hline match-up & + & $\begin{array}{l}\text { Dummy } \\
\text { value }\end{array}$ & 0.19 & $1.80^{*}$ & 0.27 & $2.57^{* *}$ \\
\hline high-tech firm & + & $\begin{array}{l}\text { dummy } \\
\text { value }\end{array}$ & -0.14 & -1.26 & -0.22 & $-2.05^{* *}$ \\
\hline actor & 0 & $\begin{array}{l}\text { dummy } \\
\text { value }\end{array}$ & -0.20 & $-1.84^{*}$ & -0.07 & -0.65 \\
\hline singer & 0 & $\begin{array}{l}\text { dummy } \\
\text { value }\end{array}$ & 0.14 & 1.30 & 0.01 & 0.10 \\
\hline athlete & 0 & $\begin{array}{l}\text { dummy } \\
\text { value }\end{array}$ & 0.05 & 0.42 & 0.05 & 0.43 \\
\hline gender & 0 & $\begin{array}{l}\text { dummy } \\
\text { value }\end{array}$ & 0.01 & 0.07 & -0.06 & -0.50 \\
\hline age & 0 & real value & 0.05 & 0.42 & 0.08 & 0.69 \\
\hline $\begin{array}{c}\text { Multi- } \\
\text { celebrities }\end{array}$ & + & $\begin{array}{l}\text { dummy } \\
\text { value }\end{array}$ & 0.02 & 0.21 & 0.15 & 1.43 \\
\hline $\begin{array}{c}\text { Multi- } \\
\text { endorsement }\end{array}$ & 0 & $\begin{array}{l}\text { dummy } \\
\text { value }\end{array}$ & -0.10 & -0.97 & -0.06 & -0.55 \\
\hline assets of firm & 0 & real value & -0.07 & -0.63 & -0.08 & -0.70 \\
\hline book value & + & real value & -0.02 & -0.17 & 0.19 & $1.74^{*}$ \\
\hline
\end{tabular}

note : ${ }^{*}$ means significant at $10 \%$ level, ${ }^{* *}$ means significant at $5 \%$ level。 Multi-celebrities $=$ one product or brand is endorsed by several celebrities Multi-endorsement $=$ one celebrity endorses several products or brands .

\section{DISCUSSION AND CONCLUSION}

This study examines the relationships between the celebrity endorsement and the abnormal stock return of the endorsed firm. Specifically, the study analyses whether the celebrity’s demographics (age, gender and occupation) would affect the firm's financial performance measured by abnormal return in stock exchanges. The study provides insights 
into appropriate use of celebrity endorsement by various firms. Event study method is used to analyze whether media announcement and match-up of celebrity endorsement would have impact on the abnormal stock return. The results show that the celebrity demographics have insignificant effects on the endorsed firm’s abnormal financial return. However, investors seem to react negatively towards actor celebrity endorsement, particularly on high-tech products. The findings indicate that investors prefer high-tech firms not to use celebrities, especially actors, for endorsing the products or brands. Nevertheless, investors are optimistic about match-up endorsement albeit showing no response to media announcement. Detail discussion is as follows.

\subsection{Celebrity Factors and Endorsement Outcome}

Consistent with Ding et al.’s (2011) study, this research shows that celebrities' age and gender have no impact on their endorsement outcome. Although it is prevalent for firms to use popular actors for endorsement, the study shows that investors and consumers react negatively towards actor celebrity endorsements. Using actors to endorse products is one of the most popular and expensive advertising tools in China. This often results from a popular role in a movie or TV program played by an actor. Marketers use the actor's popularity to attract consumers' attention to the firm's products. The finding of this study implies that marketers and senior management should be cautioned to use actor celebrities. Despite their fame and popularity in the entertainment industry, consumers often associate actors with exaggeration and hypocrisy, and with being lack of professionalism and expertise. Many undesirable incidents occurred in past years due to actors' untruthful endorsement, which has resulted in discredit in consumers' perception. This finding accounts for investors' optimism 
on match-up endorsement. Actors by no means match their expertise with the products they endorse.

\subsection{Factors Associating with the Endorsed Firms and Endorsement Outcome}

Interestingly, stock market reacts negatively to celebrity endorsement for high-tech

products. This finding is contrasting to that of previous research (Ding et al., 2011). This

result may be attributed to current market situations in China. Fake or imitation products are prevalent in this country. Quality of authentic products or brands often fails to conform to claimed standards or labeled specifications. Celebrity endorsement becomes a mere marketing tool to promote the brand and attract consumers’ attention. In many cases, celebrities are motivated by endorsing fee or commission, but rarely consume the products they have endorsed. This counter-affects consumers’ confidence and trust in such endorsements. Consumers today are very knowledgeable and able to access to the relevant information through various social media about the product they intend to purchase. They are generally aware of distinction between popularity of the actor and quality of the product they intend to purchase. In the case of high-tech products, the celebrities may not even understand the product attributes or functions, except being trained to say or act what is instructed. Investors or consumers have become alert and developed caution towards celebrity endorsements.

The positive relationship between the firm's book value and the abnormal stock return generated from celebrity endorsement is plausible. The book value is indicative of the firm's financial status. Understandably celebrity endorsement is expensive. If a firm with a negative book value use celebrities, investors may lose confidence in the outcome. On the contrary, 
investors would believe that using celebrities to endorse the product or brand for the firm with sound financial status may enhance the sales and profitability. The negative and insignificant effect exerted by the firm's assets indicates that the assets are unreliable source of the firm's finance. Indeed assets are unstable indicators and affected by many variables including the market situations and the firm's relationships with other stakeholders.

\subsection{Media Announcement Match-Up Endorsement}

In general, the stock market is responsive to any major change to the firm. Employing celebrities for endorsing the firm's products is a major event as the cost incurred on the celebrity is substantial. Marketers expect to generate some positive return and achieve optimal profitability through such endorsement. The firm often holds press conference to make announcement about the celebrity with intention to stimulate interests in investors and consumers. However, findings of this study show that investors are rather irresponsive to such announcement. No significant rise occurs in the firm's share price after the announcement. They are probably dubious of positive return from investing on a celebrity, holding a wait-and-see attitude.

Although the findings of this study show that media announcement fails to stimulate investors' interest and the stock market, abnormal stock return is generated from using the match-up celebrities. Investors are particularly interested in investing the firm that uses celebrities in the right profession with good reputations, for instance, $\mathrm{Li} \mathrm{Na}$, the tennis champion for endorsing tennis rackets and the sort. However, in Ding et al.’s (2011) study, an insignificant relationship was reported. The inconsistency may be attributed to the firms selected for the study context. 


\section{IMPLICATIONS AND FUTURE STUDY}

The current study has implications for the relevant literature and practitioners. Very few studies have used abnormal stock return and event method to measure celebrity endorsement effectiveness. This study provides insights into the influence of attributes associated with celebrities and the endorsed firm on the value of celebrity endorsement, extending the celebrity endorsement research into a broader domain. In particular, this study has practical implications for firms that have used or intend to use celebrity endorsement, especially for those in China. Celebrity endorsement advertising overwhelms most Chinese TV channels. The majority of these celebrities are popular actors. This study finds that actor endorsement is counter effective. This finding may account for effectiveness of match-up endorsement. Actors and other screen stars may not match up with any product endorsed. Findings of this study alert marketers and the relevant agencies on appropriate selection and use of celebrities to endorse a product or brand. Marketing indeed facilitates exchange between the business and other stakeholders. In the case of high-tech products, celebrity endorsement may not be an effective marketing tool to promote the products according to findings of this study. High-tech firms should seek alternative means to obtain consumer trust, investors’ interest and to achieve competitive advantage.

A few limitations arise from this study and present a direction for future research. Sampling of the current study is focused on the cases in China, which limits generalization of the findings. The cases are taken from those listed in two Stock Exchanges. The results may not apply to the firms that are listed in other stock exchanges or not listed at any stock exchange but have used celebrity endorsement. Future research will look into these aspects. 
Given that celebrity endorsement is overwhelmingly prevalent in China, further studies should attend to the rationale behind this prevalence and provide a better understanding of endorsement value.

\section{References}

Agrawal, J., \& Kamakura, W. A. (1995). The economic worth of celebrity endorsers: An event study analysis. The Journal of Marketing, 56-62..

Armstrong Jr, G. M. (1990). Reification of Celebrity: Persona as Property, The. La. L. Rev., 51, 443.

Asian Women (2015). Http://Women.Asiaone.Com/Women/People/Cecilia-Cheung-FiredHow-She-Lost-Protector-Who-Stood-Her-Every-Time-Nicholas-Tse-Let. Posted On 22 March, 2015.

Armstrong Jr, G. M. (1990). Reification of Celebrity: Persona as Property, The. La. L. Rev., 51, 443.

Biswas, D., Biswas, A., \& Das, N. (2006). The differential effects of celebrity and expert endorsements on consumer risk perceptions. The role of consumer knowledge, perceived congruency, and product technology orientation. Journal of Advertising, 35(2), 17-31.

Boyd, T. C., \& Shank, M. D. (2004). Athletes as Product Endorsers: The Effect of Gender and Product Relatedness. Sport Marketing Quarterly, 13(2).

Byrne, A., Whitehead, M., \& Breen, S. (2003). The naked truth of celebrity endorsement. British Food Journal, 105(4/5), 288-296. 
Chan, K., Leung Ng, Y., \& Luk, E. K. (2013). Impact of celebrity endorsement in advertising on brand image among Chinese adolescents.Young Consumers, 14(2), 167-179.

Clark, J. M., Cornwell, T. B., \& Pruitt, S. W. (2002). Corporate stadium sponsorships, signalling theory, agency conflicts and shareholder wealth.Journal of Advertising Research, 42(6), 16-32.

Cornwell, T. B., Pruitt, S. W., \& Van Ness, R. (2001). The value of winning in motorsports: sponsorship-linked marketing. Journal of Advertising Research,41(1), 17-31.

Ding, H., Molchanov, A. E., \& Stork, P. A. (2011). The value of celebrity endorsements: A stock market perspective. Marketing Letters, 22(2), 147-163.

Escalas, J. E., \& Bettman, J. R. (2009). Connecting with celebrities: Celebrity endorsement, brand meaning, and self-brand connections. Journal of Marketing Research.

Fashionbi (2014). Http://Fashionbi.Com/Newspaper/Chinese-Celebrity-Fan-BingbingBoosts-74m-Online-Sales-In-2013. Published On 7 Jan, 2014.

Fink, J., Kenix, L. J., \& Cunningham, G. (2004). Utilizing athletes as endorsers to sell women's sport: Attractiveness versus expertise. Journal Of Sport Management 18(4), 350-367.

Fizel, J., McNeil, C. R., \& Smaby, T. (2008). Athlete endorsement contracts: the impact of conventional stars. International Advances in Economic Research, 14(2), 247-256.

Gabor, A., Thorton, J., \& Wienner, D. P. (1987). Star turns that can turn star-crossed. US News and World Report, 103(23), 57.

Gan, W. (2006). Effectiveness of Celebrity Endorsement Advertising in Chinese Marketplace. Retrieved March, 15, 2013. 
Hsu, C. K., \& McDonald, D. (2002). An examination on multiple celebrity endorsers in advertising. Journal of Product \& Brand Management, 11(1), 19-29.

Hung, K., Chan, K. W., \& Caleb, H. T. (2011). Assessing celebrity endorsement effects in China. Journal of Advertising Research, 51(4), 608-623.

Hung, K., Chan, K. W., \& Caleb, H. T. (2011). Assessing celebrity endorsement effects in China. Journal of Advertising Research, 51(4), 608-623.

Jain, V. (2011). Celebrity endorsement and its impact on sales: A research analysis carried out in India. Global Journal of Management and Business Research, 11(4).

Kamins, M. A., \& Gupta, K. (1994). Congruence between spokesperson and product type: A matchup hypothesis perspective. Psychology \& Marketing,11(6), 569-586.

Koernig, S. K., \& Boyd, T. C. (2009). To catch a tiger or let him go: The match-up effect and athlete endorsers for sport and non-sport brands. Sport Marketing Quarterly, 18(1), 25.

Louie, T. A., \& Obermiller, C. (2002). Consumer response to a firm's endorser (dis) association decisions. Journal of Advertising, 31(4), 41-52.

Lynch, J., \& Schuler, D. (1994). The matchup effect of spokesperson and product congruency: A schema theory interpretation. Psychology \& Marketing, 11(5), 417445.

MacKinlay, A. C. (1997). Event studies in economics and finance. Journal of economic literature, 35(1), 13-39.

McCracken, G. (1989). Who is the celebrity endorser? Cultural foundations of the endorsement process. Journal of consumer research, 16(3), 310-321. 
Misra, S., \& Beatty, S. E. (1990). Celebrity spokesperson and brand congruence: An assessment of recall and affect. Journal of Business Research, 21(2), 159-173.

Mittelstaedt, J. D., Riesz, P. C., \& Burns, W. J. (2000). Why are endorsements effective? Sorting among theories of product and endorser effects. Journal of Current Issues \& Research in Advertising, 22(1), 55-65.

Ohanian, R. (1990). Construction and validation of a scale to measure celebrity endorsers' perceived expertise, trustworthiness, and attractiveness.Journal of advertising, 19(3), $39-52$.

Petty, R. D., \& Lindsey-Mullikin, J. (2006). The regulation of practices that promote brand interest: a "3Cs" guide for consumer brand managers. Journal of Product \& Brand Management, 15(1), 23-36.

Petty, R. E., Cacioppo, J. T., \& Schumann, D. (1983). Central and peripheral routes to advertising effectiveness: The moderating role of involvement.Journal of consumer research, 10(2), 135-146.

Russell, M., Mahar, J. and Drewniak, B. (2005). Examination of stock market response to publicity surrounding athletic endorsers. Marketing Management Joumal, 15(2), 6779.

Seno, D., \& Lukas, B. A. (2007). The equity effect of product endorsement by celebrities: A conceptual framework from a co-branding perspective.European Journal of Marketing, 41(1/2), 121-134.

Silvera, D. H., \& Austad, B. (2004). Factors predicting the effectiveness of celebrity endorsement advertisements. European Journal of marketing,38(11/12), 1509-1526. 
Spry, A., Pappu, R., \& Bettina Cornwell, T. (2011). Celebrity endorsement, brand credibility and brand equity. European Journal of Marketing, 45(6), 882-909.

Street, J. (2004). Celebrity politicians: popular culture and political representation. The British journal of politics and international relations, 6(4), 435-452.

Taneja, M. (2014). How to choose and measure the value of a celebrity endorsement. marketing. Http://Www.Thesmartcube.Com/Insights/Marketing/Item/.

Till, B. D., \& Busler, M. (1998). Matching products with endorsers: attractiveness versus expertise. Journal of consumer marketing, 15(6), 576-586.

Till, B. D., \& Busler, M. (2000). The match-up hypothesis: Physical attractiveness, expertise, and the role of fit on brand attitude, purchase intent and brand beliefs. Journal of advertising, 29(3), 1-13.

Tripp, C., Jensen, T. D., \& Carlson, L. (1994). The effects of multiple product endorsements by celebrities on consumers' attitudes and intentions. Journal of consumer research, 20(4), 535-547.

White, D. W., Goddard, L., \& Wilbur, N. (2009). The effects of negative information transference in the celebrity endorsement relationship. International Journal of Retail \& Distribution Management, 37(4), 322-335. 